\title{
Effects of Kenaf Loading and Alkaline Treatment on Properties of Kenaf Filled Natural Rubber Latex Foam
}

\author{
(Kesan Pembebanan Kenaf dan Perawatan Alkali ke atas Sifat Busa Lateks Getah Asli Terisi Kenaf)
}

\author{
AHMAD FIKRI ABDUl KARIM, HANAFI ISMAIL* \& ZULKIFLI MOHAMAD ARIFF
}

\begin{abstract}
This research was carried out to study the effects of kenaf loading and alkaline treatment on tensile properties, density, thermal and morphological properties of kenaf filled natural rubber latex foam (NRLF). Samples were prepared using a Dunlop method. From the results, increasing loading of kenaf reduced the tensile strength and elongation at break for both samples, treated and untreated kenaf filled NRLF. Meanwhile, modulus at 100\% elongation and density increased with an increased in kenaf loading. Samples with treated kenaf showed higher tensile strength, modulus at 100\% elongation and density but low in elongation at break as compared with samples with untreated kenaf. Thermal study by using thermogravimetric analysis (TGA) showed that thermal stability reduced with increased in kenaf loading for both samples. Samples with treated kenaf have higher thermal stability compared with samples of untreated kenaf. The filler-matrix interaction and the pores size variation of both samples was clearly seen in the micrograph images by using scanning electron microscope (SEM).
\end{abstract}

Keywords: Alkaline treatment; foam; kenaf; latex

\section{ABSTRAK}

Kajian ini dilakukan untuk mengkaji kesan pembebanan kenaf dan perawatan alkali ke atas sifat tensil, ketumpatan, terma dan morfologi busa lateks getah asli terisi kenaf (NRLF). Sampel telah disediakan menggunakan kaedah Dunlop. Keputusan menunjukkan pertambahan pembebanan kenaf mengurangkan kekuatan tensil dan pemanjangan pada takat putus untuk kedua-dua sampel NRLF terisi kenaf terawat dan tidak terawat. Manakala, modulus pada 100\% pemanjangan dan ketumpatan meningkat dengan peningkatan pembebanan kenaf. Sampel dengan kenafterawat menunjukkan kekuatan tensil, modulus pada $100 \%$ pemanjangan dan ketumpatan yang lebih tinggi tetapi rendah pemanjangan pada takat putus berbanding sampel dengan kenaf tidak terawat. Kajian terma menggunakan analisis termogravimetrik (TGA) menunjukkan kestabilan terma berkurang dengan peningkatan pembebanan kenaf untuk kedua-kedua sampel. Sampel dengan kenaf terawat mempunyai kestabilan terma yang lebih tinggi berbanding sampel tanpa rawatan. Interaksi pengisi-matriks dan perubahan saiz liang di dalam kedua-dua sampel boleh dilihat dengan jelas di dalam imej mikrograf menggunakan mikroskop elektron imbasan (SEM).

Kata kunci: Busa; kenaf; lateks; perawatan alkali

\section{INTRODUCTION}

Natural rubber latex (NRL) is one of the natural commodities which have outstanding economic and strategic importance has been used in various engineering applications (Roslim et al.2012). The unique characteristics of NRL such as high strength, flexibility and elasticity have attracted much attention and are becoming progressively significant for numerous engineering applications (Amir \& Moris 1999; Nur Hanis et al. 2017). NRL was well known in production of extruded threads, dipped goods, adhesives, carpet-backing and molded foams (Blackey 1997). Natural rubber latex foams (NRLF) are one of the applications of NRL. Latex foam is defined as a cellular rubber that has been made directly from liquid latex (Karim et al. 2016). NRLF which is prepared in accordance with the most favorable procedure has a fine-porous uniform structure (Tsarevskii \& Irgen 1995).
The most important single event in the development of the latex foam rubber industry was probably the development of the Dunlop process in late 1920s (Karim et al. 2016). Natural latex foams have been used as mattresses, cushioning seats at concert halls, theatres, hotels, houses and vehicles. Recently, major interest in incorporation of fibers into NRLF has been studied (Ramasamy et al. 2012).

Lately, the interest of using of natural and renewable reinforcing fiber especially natural reinforcing fibers from several sources of nature has attracted the attention of the worldwide coomunity and increased rapidly (Dahham et al. 2015; Sharifah Nurul Ain et al. 2016). Bio-fibers used in polymers generally originated from plant such as banana, sisal, hemp, jute, pineapple, bamboo, cotton, coconut, rice husk and kenaf (Han et al. 2012). Natural fiber composites were used in numerous applications due to various desirable properties that they offered such as 
light weight, renewability, low cost and environmentally friendly (Muniandy et al. 2012). Kenaf (Hibiscus cannabinus L.) in Malaysia can potentially replace the existance of well known bio-fiber, as well as promote and develop the related industry (Salman et al. 2015). The fibers extracted from the kenaf's bast can be used as the alternative reinforcement in polymeric composites. The kenaf fiber is single, straight, and without branch and it grows quickly, rising to four to five meter tall in a four to five month growing season and $25-35 \mathrm{~mm}$ in original diameter. Kenaf's composites can be improved by either chemical or physical processes (Fiore et al. 2015). The compatibility between kenaf and the matrix, structure and surface of kenaf fiber can be improved by chemical or physical treatment on kenaf fibre (Majid et al. 2016). To the best of our knowledge, no study has been reported the use of kenaf in NRLF. Therefore, kenaf was chosen in this study.

The objective of this research was to study the effects of kenaf loading and alkaline treatment on tensile properties, density, thermal and morphological properties of kenaf filled Natural Rubber Latex Foam (NRLF).

\section{METHODS}

\section{MATERIALS AND FORMULATION}

Table 1 shows the formulation and materials used in this research. Natural rubber latex (Low Ammonia (LATZ) type) and the required chemicals for preparation latex foam were purchased from Zarm Scientific \& Supplies Sdn. Bhd, Malaysia. Kenaf fiber was supplied by National Kenaf and Tobacco Board.

\section{KENAF POWDER ALKALINE TREATMENT}

Initially kenaf fibers were immersed in sodium hydroxide $(\mathrm{NaOH})$ solutions ( $\mathrm{pH} 10)$ for $3 \mathrm{~h}$ at ambient temperature. Then, the immersed kenaf was rinsed and immersed with distilled water to remove traces of alkali from the kenaf fiber. The washing process was repeated and continued until the $\mathrm{pH}$ of water after washing is approximately 7 . After that, kenaf fibers were dried at ambient temperature for $72 \mathrm{~h}$. After $72 \mathrm{~h}$, kenaf were ground and sieved into an average particle size of less than $300 \mu \mathrm{m}$.

\section{SAMPLE PREPARATION}

First, the filtered LATZ latex was measured according to the required amount followed by stirred the latex using a mechanical stirrer for about $15 \mathrm{~min}$. After $15 \mathrm{~min}$, sulphur and antioxidant were added and stirred at $10 \mathrm{rpm}$. After 30 min, ZMBT and ZDEC were slowly added to the mixture and continued stirred about $1 \mathrm{~h}$. After $1 \mathrm{~h}$, potassium oleate soap and a predetermined volume of kenaf powder were added to the compound slowly and the NRLF compound was then matured for $6 \mathrm{~h}$ at room temperature with a continuous stirring speed of $6 \mathrm{rpm}$. After the maturation process, the NRLF compound was beaten intensively and foamed using the stand mixer (KENWOOD, kMix) until the volume was increased up to three times of the initial volume. The compound was beating time of about $5 \mathrm{~min}$ at maximum speed and once the desired volume obtained, the foaming speed was lowered to obtained fine and even foam. Next, DPG together with zinc oxide $(\mathrm{ZnO})$ were added to the foam and beating was continued for another $1 \mathrm{~min}$. Then, SSF was added and the foam was beaten for 45 min. Finally, the un-gelled foam was quickly poured into the desired aluminum mould and allowed to gel for $3 \mathrm{~min}$ at ambient temperature. Gelled foam was then cured in an oven at $105^{\circ} \mathrm{C}$ for $2 \mathrm{~h}$. Once the foam has cured, the foam was stripped from the mould and washed thoroughly with de-ionized water to remove potassium oleate soap and excessive non-reacted materials. After washing, the cured NRLF was evenly dried in a hot air oven at $80^{\circ} \mathrm{C}$ for $8 \mathrm{~h}$.

\section{MEASUREMENT OF TENSILE PROPERTIES}

The tensile test for the treated and untreated kenaf filled NRLF samples was performed by using universal testing machine Instron 3366 according to ISO 48. Dumbbellshaped samples were cut from the samples using Wallace die cutter. The test was performed at ambient temperature with a crosshead speed of $500 \mathrm{~mm} / \mathrm{min}$. Five samples of each kenaf loading for both treated and untreated kenaf

TABLE 1. Formulation of kenaf filled NRLF

\begin{tabular}{lcc}
\hline Ingredients & $\begin{array}{c}\text { Total solid } \\
\text { content }(\%)\end{array}$ & $\begin{array}{c}\text { Formulation } \\
(\mathrm{pphr})\end{array}$ \\
\hline LA Latex & 60 & 100 \\
Sulphur & 50 & 2.2 \\
Antioxidant & 50 & 1 \\
Potassium oleate & 20 & 4.5 \\
Zinc diethyldithiocarbamate (ZDEC) & 50 & 0.9 \\
Zinc 2-mercaptobenzhiozolate (ZMBT) & 50 & 0.9 \\
Zinc Oxide & 50 & 3 \\
Diphenyl guanidine (DPG) & 40 & 0.3 \\
Sodium silicofluoride (SSF) & 25 & 1.2 \\
Kenaf powder & 25 & $1 / 3 / 5 / 7$ \\
\hline
\end{tabular}


filled NRLF were tested, and the average were reported. Tensile properties such as tensile strength, tensile modulus and elongation at break were obtained from this test.

\section{DENSITY TEST}

The density of treated and untreated kenaf filled NRLF was determined by calculation from the mass and volume of a specimen as shown in (1). Samples used in this test method were in a regular shape not less than $16 \mathrm{~cm}^{3}$ in volume (according ASTM D1056).

Five samples of each kenaf loading were measured and average of results was reported.

$$
\text { Density }\left(\mathrm{kg} / \mathrm{m}^{3}\right)=\mathrm{A} / \mathrm{B}
$$

where $\mathrm{A}$ is the mass of the specimen $(\mathrm{kg})$ and $\mathrm{B}$ is the volume of the specimen $\left(\mathrm{m}^{3}\right)$.

\section{SCANNING ELECTRON MICROSCOPY}

Surface morphology of treated and untreated kenaf filled NRLF was studied by using scanning electron microscope (Hitachi, TM1000). The foam surfaces were mounted on aluminum stubs and sputter-coated with a thin layer of gold to avoid electrostatic charging and poor image resolution during examination. The morphology of the treated and untreated kenaf filled NRLF were observed.

\section{THERMOGRAVIMETRIC ANALYSIS (TGA)}

TGA of the kenaf-filled NRLF samples was conducted by using Perkin Elmer Pyris 6 testing instrument (USA). Samples of the kenaf filled NRLF were tested at a heating rate of $20^{\circ} \mathrm{C} / \mathrm{min}$ from 30 to $600^{\circ} \mathrm{C}$ under nitrogen gas conditions. The TGA values were recorded.

\section{RESULTS AND DISCUSSION}

\section{TENSILE PROPERTIES}

Figure 1 shows the tensile strength of treated and untreated kenaf filled NRLF at different filler loading. Both samples of kenaf filled NRLF show decrement in tensile strength as the kenaf loading was increased. Tensile strength of samples with untreated kenaf decrease from $0.48 \mathrm{MPa}$ (for the control sample) to $0.22 \mathrm{MPa}$ (sample with 7 phr kenaf loading) and samples with treated kenaf decreased from 0.48 to $0.26 \mathrm{MPa}$. As can be seen in Figure 1, kenaf filled NRLF with treated kenaf have higher tensile strength as compared with samples with untreated kenaf. This enhancement was due to the decrease in cell size of the foams which can be observed later in SEM micrographs. As mentioned earlier, the compatibility between kenaf and the matrix as well as structure and surface of kenaf fiber can be improved by chemical or physical treatment on kenaf fibre. Alkaline treatment on kenaf fiber leads to the increased of surface roughness of the fiber. The increament in the surface roughness of the fiber resulting in better mechanical interlocking between kenaf and matrix latex.

Figure 2 shows the value of elongation at break for treated and untreated kenaf filled NRLF at different filler loadings. From Figure 2, increase in filler loading cause reduction in the elongation at break for both groups of samples. For samples with treated kenaf, the elongation at break was higher than the elongation at break for samples with untreated kenaf. The elongation at break for samples with untreated kenaf reduced from $441.7 \%$ to $282.7 \%$ while samples with treated kenaf reduced from $441.7 \%$ to $340.8 \%$ for samples with zero kenaf loading and those of having 7 phr kenaf loading. By using treated kenaf in NRLF, mechanical interaction was improved which prevent the stress propagation to occur at lower strain and made the samples less brittle. Therefore, the samples with treated kenaf are more likely to experiencing higher elongation instead of fail at lower strain.

Figure 3 shows the value of modulus at $100 \%$ elongation (M100) of treated and untreated kenaf filled NRLF at different filler loading. The M100 increased with increased of kenaf loading for both samples. At similar kenaf loading, sample with untreated kenaf exhibited

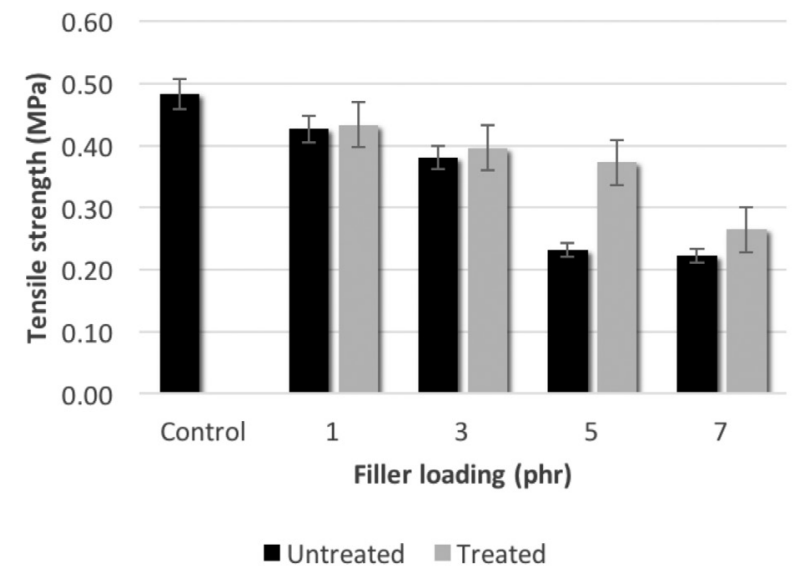

FIGURE 1. Tensile strength of treated and untreated kenaf filled NRLF at different filler loading

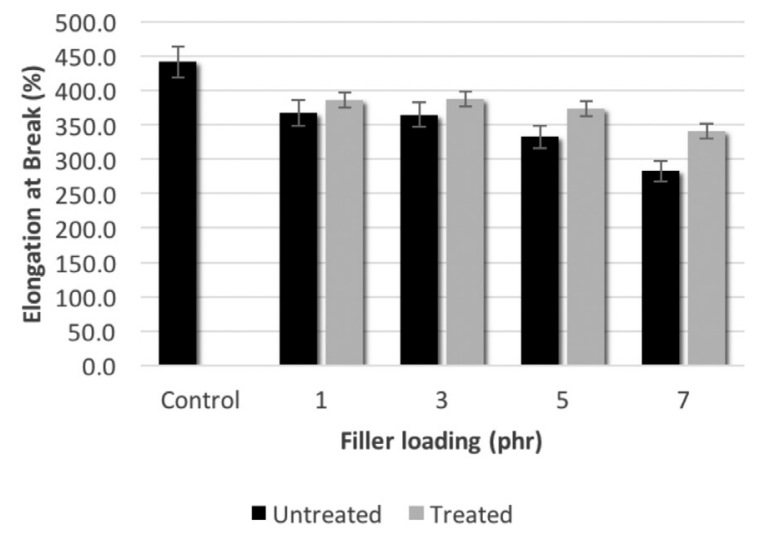

FIGURE 2. Elongation at break (\%) of treated and untreated kenaf filled NRLF at different filler loading 


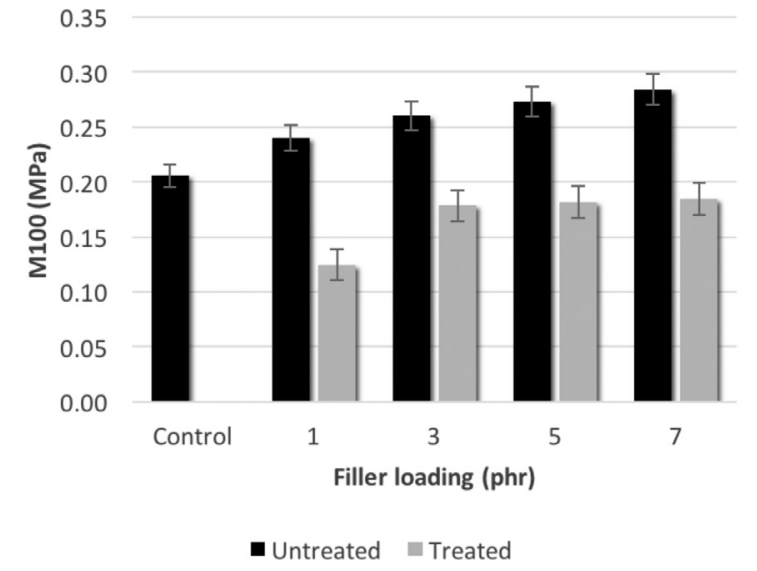

FIGURE 3. M100 of treated and untreated kenaf filled NRLF at different filler loading

the high value of M100 as compared with samples with treated kenaf. The M100 for sample with untreated kenaf increased from 0.21 to $0.28 \mathrm{MPa}$ while M100 for sample with treated kenaf increased from 0.12 to $0.18 \mathrm{MPa}$. The existence of treated kenaf in the composites system give a positive effect on the M100 due to the elasticity of foam was increased, resulting in less stiff and rigid foam. The increasing trend in M100 was observed as a consequent of the elasticity of the foam was reduced, resulting in stiffer, more rigid foam which decreased its resistance to breakage (Majid et al. 2016).

\section{DENSITY TEST}

Figure 4 shows the density for treated and untreated kenaf filled NRLF. The density for both samples increased with increased in kenaf loading. The density of samples with untreated kenaf increased from 119 to $195 \mathrm{~kg} / \mathrm{m}^{3}$ while the density of samples with treated kenaf increased from 167 to $211 \mathrm{~kg} / \mathrm{m}^{3}$. Kenaf fiber contributed to an increased in mass of kenaf filled NRLF which lead to the increased in density as kenaf loading increased. However, samples with treated kenaf have higher density compared with samples of untreated kenaf due to the pores size factor. The pore size of the treated kenaf filled NRLF was smaller

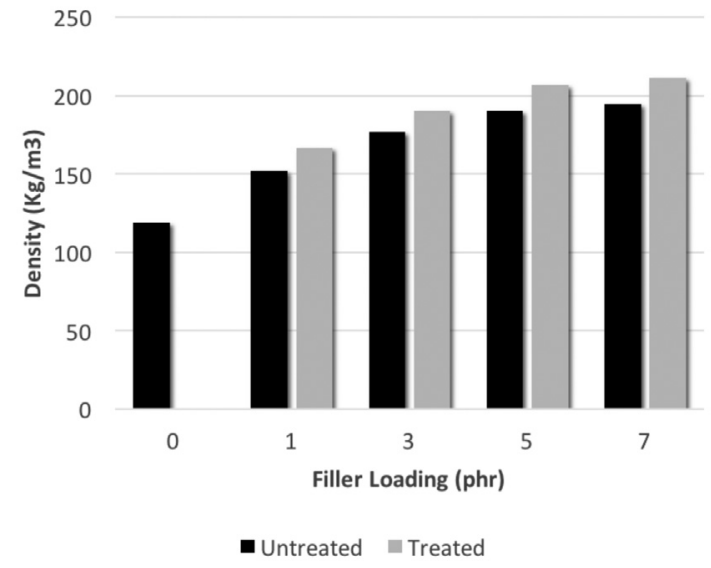

FIGURE 4. Density of treated and untreated kenaf filled NRLF at different filler loading

and uniform compared with samples of untreated kenaf as shown in SEM later. The reducing in pores size produced a more compact and high density of NRLF. The reducing in pore size was due to the better filler matrix interaction between kenaf and latex. In order to reduce the flaws during formation of foams, the filler matrix interaction was crucial in producing of uniform pore size of NRLF.

\section{THERMOGRAVIMETRIC ANALYSIS (TGA)}

Figure 5 shows the weight loss trend for treated kenaf filled NRLF. The weight loss of the kenaf-filled NRLF with increasing temperature under a nitrogen environment was measured and graphs of the weight loss (\%) as a function of the temperature were plotted.

Table 2 shows the temperature at $50 \%$ weight loss $\left({ }^{\circ} \mathrm{C}\right)$, the maximum weight loss $(\%)$ and the final char residue (\%). Based on the results, increased the amount of kenaf loading, reduced the thermal stability for both samples. Increasing the amount of kenaf reduced the thermal stability due to the decomposition of the cellulose occurred at lower temperatures (Matheus Poletto et al. 2014). As shown in Table 2, the thermal stability of the samples was reduced due to the increased in cellulosic volume. Cellulosic materials can promote the ignitability,

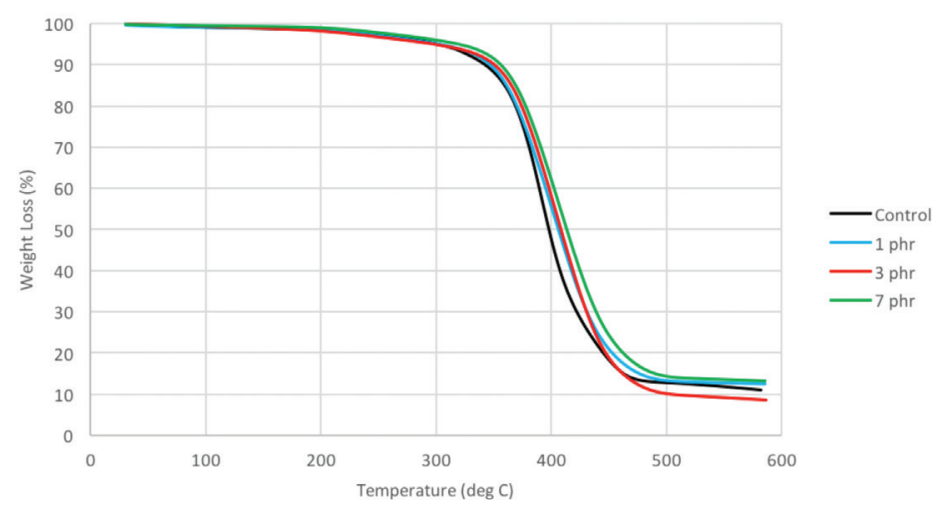

FIGURE 5. TGA curved of treated kenaf filled NRLF at different filler loading 
TABLE 2. Thermal stability parameters of treated and untreated kenaf filled NRLF

\begin{tabular}{ccccccc}
\hline & $\begin{array}{c}\text { Temperature at 50\% weight } \\
\text { loss }\left({ }^{\circ} \mathrm{C}\right)\end{array}$ & \multicolumn{2}{c}{$\begin{array}{c}\text { Maximum weight } \\
\text { loss }(\%)\end{array}$} & \multicolumn{2}{c}{$\begin{array}{c}\text { Final char residue } \\
(\%)\end{array}$} \\
\hline Sample & Untreated & Treated & Untreated & Treated & Untreated & Treated \\
control & 398 & - & 94.9 & - & 4.5 & - \\
$1 \mathrm{phr}$ & 378 & 416 & 95.3 & 86.7 & 4.9 & 4.3 \\
$3 \mathrm{phr}$ & 374 & 413 & 95.5 & 87.3 & 7.3 & 7.1 \\
$7 \mathrm{phr}$ & 374 & 409 & 95.6 & 91.0 & 7.8 & 7.3 \\
\hline
\end{tabular}

thus they accelerated the degradation process. Hence by increasing the amount of kenaf at a certain loading, the thermal stability of the kenaf-filled NRLF reduced.

Treated kenaf filled NRLF showed higher thermal stability compared with untreated kenaf filled NRLF due to the better interaction between kenaf and matrix (latex). The higher char residue was produced by the kenaf filled NRLF at $7 \mathrm{phr}$ kenaf loading as compared to the other loading for both samples.

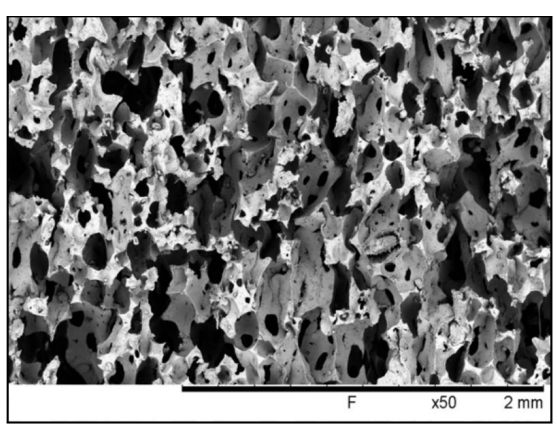

(a)

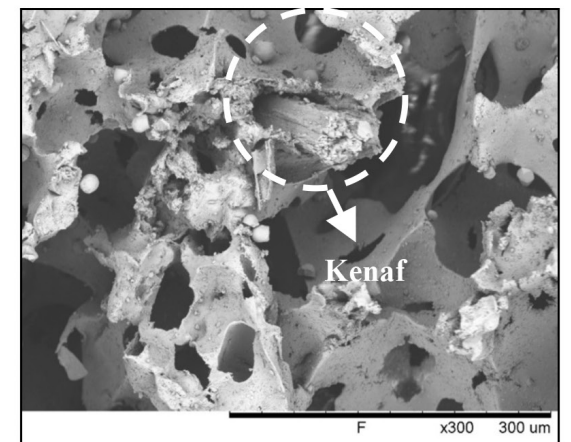

(c)

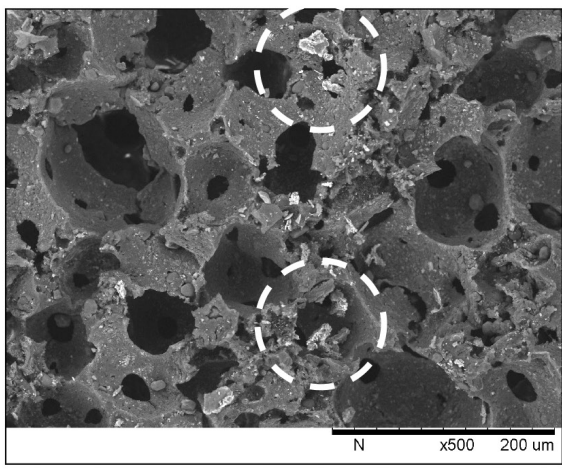

(e)

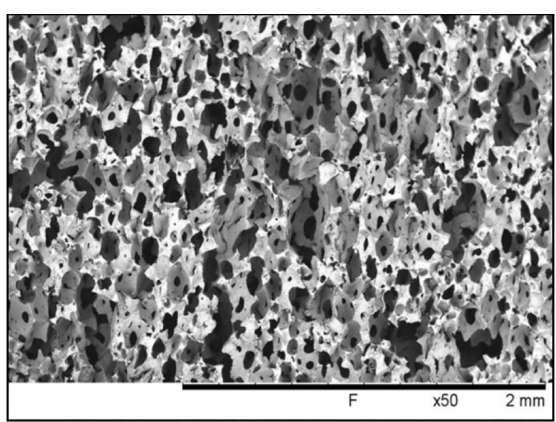

(b)

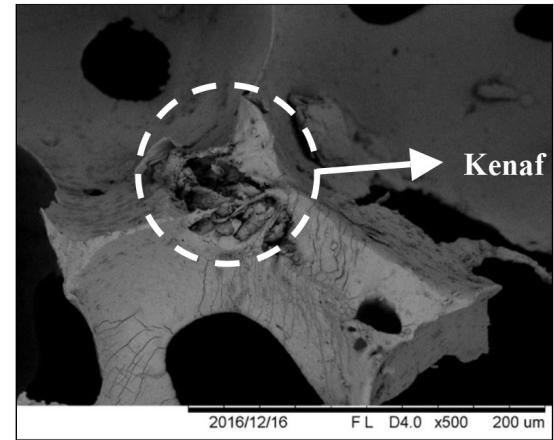

(d)

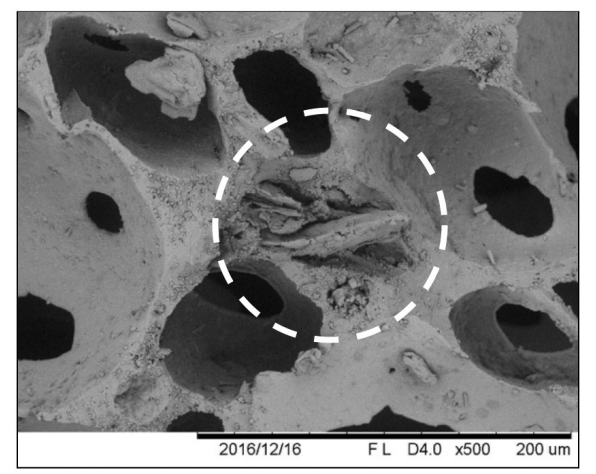

(f)

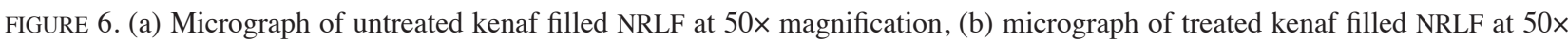
magnification, (c) Micrograph of untreated kenaf in kenaf filled NRLF, (d) Micrograph of treated kenaf in kenaf filled NRLF, (e) agglomeration of untreated kenaf in NRLF at 7 phr kenaf loading and (f) agglomeration of treated kenaf in NRLF at 7 phr kenaf loading 


\section{MORPHOLOGICAL PROPERTIES}

Figure 6 represented the influence of treated kenaf incorporation on morphologies of kenaf filled NRLF. From Figure 6(a) and Figure 6(b), both samples clearly show open cell structures. Comparatively, sample with treated kenaf show small pores and stable size of cell structured as compared with sample with untreated kenaf. This proved that the addition of treated kenaf to the system reduced the pores size and gave the better cell structures to the latex foam. Figure 6(c) and Figure 6(d) shows the filler-matrix interaction of untreated and treated kenaf filled NRLF at 5 phr kenaf loading. From Figure 6(c), sample with untreated kenaf showed weak filler-matrix interaction while sample with treated kenaf on Figure 6(d) shows good filler-matrix interaction which leads to the increased in tensile properties. This is an indication that the alkaline treatment was able to increase the adhesion at the filler-matrix interfaced which resulted an increased in the tensile strength as well as the modulus of kenaf filled NRLF. Increased in kenaf loading reduced the tensile strength of both samples. This was due to the agglomeration of kenaf in latex foam which can be seen in Figure 6(e) and Figure 6(f). The agglomeration of kenaf act as stress concentration point and initiate the propagation of crack when stress applied. But, samples with treated kenaf exhibit less agglomeration of kenaf compared with samples with untreated kenaf. This was due to the uniformly distributed of kenaf during foaming process.

\section{CONCLUSION}

The tensile strength and elongation at break of kenaffilled natural rubber latex foam (NRLF) decreased with an increase in filler loading, while modulus at $100 \%$ elongation and density increased for both samples. Samples with treated kenaf have higher tensile strength, elongation at break and density but low in modulus at $100 \%$ elongation. From TGA curves, by increasing the amount of kenaf loading, the thermal stability of both treated and untreated kenaf filled NRLF reduced. Thermal stability of treated kenaf filled NRLF was higher than untreated kenaf filled NRLF. Morphological study by using SEM showed that samples with untreated kenaf did not bind well with the matrix, which resulted in the reduction of tensile strength. Samples with treated kenaf have better interaction with natural rubber matrix as compared with untreated kenaf samples.

\section{ACKNOWLEDGEMENTS}

The author would like to gratefully acknowledge the Research University Grant and Cluster for Polymer Composites (CPC) of Universiti Sains Malaysia (Grant Number 1001/PKT/8640014) and MyBrain 15 of Ministry of Higher Education Malaysia for the financial assistance.

\section{REFERENCES}

Amir Hashim, M.Y. \& Moris, M.D. 1999. NR latex vulcanization - prevulcanizationand postvulcanization of dipped NR latex films. Journal of Rubber Research 2: 78-87.

Blackey, D.C. 1997. High Polymer Lattices, Science and Technology. Volume 2. 2nd ed. London: Chapman \& Hall.

Dahham, O.S., Noriman, N.Z., Mohd Kahar, A.W., Ismail, H. \& Sam, S.T. 2015. The effect of sawdust loading as natural short fiber on NBR/NRL-G compounds. Journal of Applied Science and Agriculture 10(5): 33-39.

Fiore, V., Di Bella, G. \& Valenza,A. 2015. The effect of alkaline treatment on mechanical properties of kenaf fibers and their epoxy composites. Composites: Part B 68: 14-21.

Han, S.O., Karevan, M., Sim, N.I., Bhuiyan, M.A., Jang, Y.H., Ghaffar, J. \& Kalaitzidou, K. 2012. Effect of exfoliated graphite nano platelets on the mechanical and viscoelastic properties of poly (lactic acid) biocomposites reinforced with kenaf fibers. Journal of Materials Science 47: 3535-3543.

Karim, A.F.A., Ismail, H. \& Ariff, Z.M. 2016. Properties and characterization of kenaf-filled natural rubber latex foam. BioResources 1(11): 1080-1091.

Majid, N.A., Abu Bakar, S., Fadzly Radzi, M.K., Ismail, N.F., Razab Norhamidi Muhamad, M.R. \& Muhammad Azhar, K. 2016. Influence of alkaline treatment and fiber loading on the physical and mechanical properties of kenaf/polypropylene composites for variety of applications. Progress in Natural Science: Materials International 26(6): 657-664.

Matheus, P., Júnior, H.L.O. \& Ademir, J.Z. 2014. Native cellulose: Structure, characterization and thermal properties. Materials 7: 6105-6119.

Muniandy, K., Ismail, H. \& Othman, N. 2012. Fatigue life, morphological studies, and thermal aging of rattan powderfilled natural rubber composites as a function of filler loading and a silane coupling agent. BioResources 7: 841-858.

Nur Hanis Adila, A., Hamizah, M.R. \& Siti Fairus, M.Y. 2017. Epoxidation and hydroxylation of liquid natural rubber. Sains Malaysiana 46(3): 485-491.

Ramasamy, S., Ismail, H. \& Munusamy, Y. 2012. Tensile and morphological properties of rice husk powder filled natural rubber latex foam. Polymer-Plastics Technology and Engineering 51(15): 1524-1529.

Roslim, R., Amir Hashim, M.Y. \& Augurio, P.T. 2012. Natural latex foam. Journal of Engineering Science 8: 15-27.

Salman, S.D., Leman, Z., Sultan, M.T., Ishak, M.R. \& Cardona, F. 2015. Kenaf/synthetic and Kevlar $\AA /$ cellulosic fiberreinforced hybrid composites: A review. BioResources 10(4): 8580-8603.

Sharifah Nurul Ain, S.H., Sarani, Z., Chin, H.C., Fei, L.P. \& Sharifah Nabihah, S.J. 2016. Chemical and thermal properties of purified kenaf core and oil palm empty fruit bunch lignin. Sains Malaysiana 45(11): 1649-1653.

Tsarevskii, V.B. \& Irgen, L.A. 1995. Effect of foam stability on pore coherence and mechanical properties of rubber latex based material. Mechanical and Composite Materials 31: 589-592.

Ahmad Fikri Abdul Karim, Hanafi Ismail* \& Zulkifli Mohamad Ariff

School of Materials and Mineral Resources Engineering

Engineering Campus, Universiti Sains Malaysia

14300 Nibong Tebal, Pulau Pinang

Malaysia 
Hanafi Ismail*

Clusters for Polymer Composites (CPC)

Science and Engineering Research Centre

Engineering Campus, Universiti Sains Malaysia

14300 Nibong Tebal, Pulau Pinang

Malaysia
*Corresponding author; email: ihanafi@usm.my/profhanafi@ gmail.com

Received: 21 June 2017

Accepted: 21 May 2018 